УДК 78.071.22:433 (510)
DOI https://doi.org/10.31723/2524-0447-2020-30-2-35

\author{
Ши Юе \\ ORCID: 0000-0001-5165-9452 \\ аспірантка кафедри педагогіки мистецтва \\ та фортепіанного виконавства \\ факультету мистецтв імені Анатолія Авдієвського \\ Національного педагогічного університету імені М. П. Драгоманова \\ Shiyue19950204@gmail.com

\section{ОСВІТНЯ ТА КОНЦЕРТНО-ВИКОНАВСЬКА ДІЯЛЬНІСТЬ СУЧАСНИХ МУЗИКАНТІВ-ВІОЛОНЧЕЛІСТІВ КИТАЙСЬКОЇ НАРОДНОЇ РЕСПУБЛІКИ}

\begin{abstract}
Мета роботи - аналіз культурно-історичних особливостей національного музичного мистецтва Китаю. Виявлено історико-культурні передумови становлення й особливості розвитку музичного мистецтва Китаю на сучасному етапі. З'ясовано, що на цей процес впливають такі чинники, як інтеграція Китайської Народної Республіки у світовий мистецький простір, взаємообмін європейськими та східними традиціями музично-виконавської культури, збагачення теорії $і$ практики мистецького навчання в Китайській Народній Республіці найкращими досягненнями $і$ передовим досвідом закордонних фахівців, реформування національної системи масової та спеціалізованої музичної освіти, зокрема в галузі академічної підготовки виконавців-віолончелістів. У контексті иього актуальним є розкриття особливостей освітньої та концертно-виконавської діяльності професійних китайських віолончелістів, а також значення їхнього творчого доробку для розвитку сучасного інструментально-оркестрового виконавства й освіти в Китаї. Методологія дослідження спирається на системно-аналітичний, компаративні й історико-культурні методи. У матеріалах статті визначено, що початкове музично-інструментальне навчання учнів-віолончелістів реалізується в Китаї в межсах шкільної або сімейної (приватної) практики. Профільну середню та вищу музичну освіту майбутні фахівці здобувають у музичних коледжах, музичних факультетах класичних університетів, консерваторіях, академіях, а також навчальних закладах інших країн. Популяризації віолончельного виконавства в Китаї сприяють розвиток інструментально-оркестрового мистецтва, збільшення кількості камерних $і$ оркестрових колективів, організація i проведення міжнародних виконавських конкурсів, удосконалення науково-теоретичної бази та методики навчання гри на віолончелі тощо.
\end{abstract}

(C) Ши Юе, 2020 
Наукова новизна полягає у визначенні стану розвитку музичної освіти Китайської Народної Республіки, окремих характеристик професійної підготовки виконавців-віолончелістів у профільних навчальних закладах Китаю. У роботі здійснено інтерпретацію біографічних відомостей, творчого шляху й особливостей реалізації концертно-виконавської, педагогічної, організаційної й інших видів діяльності відомих китайських віолончелістів (Йо-Йо Ма, Ван Цзюнь, Тао Нi, Кан Цяосюань та інші). Зроблено спробу висвітлити індивідуально-неповторні характеристики їхнього особистісного і художнього світосприйняття, специфічні риси авторського стилю виконавства, коло музичних інтересів та уподобань. Висновки. Концертно-виконавська діяльність відомих китайських віолончелістів становить особистий внесок у розвиток сучасного інструментально-виконавського мистецтва, освіти та ії організації в Китаї й інших країнах. Розкрито високий творчий потенціал нового покоління китайських музикантів-віолончелістів.

Ключові слова: китайські віолончелісти, професійна музична освіта, концертно-виконавська діяльність, міжнародний конкурс.

Shi Yue, Graduate Student at the Department of Pedagogy of Art and Piano Performance of the Faculty of Arts named after Anatoly Avdievsky of National Pedagogical Dragomanov University

Educational, concerto and performing activity of PRC's contemporary violoncellists

Research objective. The article under consideration reveals the historical and cultural preconditions of the genesis and development specifics of Chinese contemporary music art at its contemporary stage. It was clarified that the process of music and historical disclosure of the performing artistry is predetermined by many factors, among which special significance refers to People's Republic of China's (PRC) integration in the world artistic domain; the interchange of European - East music and performing cultural traditions; the enrichment of PRC's arts education theory and practice with the best innovations and foreign experts' advanced methodological background; reformations of the national system of general and specialised music education, particularly within the field of prospective violoncellists' academic occupational training. In the context of the aforementioned issues, there appears a significance of distinguishing the specifics of the Chinese professional violoncellists' educational, concerto and performing activity, as well as the importance of their creative input for the contemporary solo and orchestra instrumental performance evolvement in China. The methodology of the research is based on the system-analytical, comparative and history-cultural method. It was determined that in China, cello player's initial training is implemented within the framework of school or private practical activity. Profiled music education, both secondary and higher, is obtained by prospective professionals at music colleges, music faculties of classical universities, conservatoires, music academies, as well as foreign professional music and pedagogical education institutions. Violoncello performance popularisation in China is contributed via world orchestra instrumental art evolvement, the growing amount of chamber and orchestra 
groups; due to arranging and conducting international music performance contests, perfecting the science and theory basis alongside with cello playing teaching methodology, etc. The scientific novelty - the following issues were accomplished: the science interpretation of biographical data, personal artistic development, specifics and individual characteristics of the practical implementation of some Chinese prominent violoncellists' (Yo-Yo Ma, Wang Jun, Tao Ni, Kang Qiaojuan and others) concerto and performing, pedagogical, organisational and other activities. An endeavour of revealing the individual and distinctive characteristics of their personal and artistic imagebearing outlook, the specific and unique features of their original performing style/manner, the focus of music interests and inclinations, was implemented. Conclusions. The Chinese contemporary violoncellists' role and personal contribution to the evolvement of both national and world instrumental and performing culture alongside with perfecting academic music education were also distinguished.

Key words: Chinese violoncellists', professional music education, concerto and performing doing, foreign competition.

Ши Юэ, аспирантка кафедры педагогики искусства и фортепианного исполнительства факультета искусств имени Анатолия Авдиевского Национального педагогического университета имени М. П. Драгоманова

Образовательная и концертно-исполнительская деятельность современных музыкантов-виолончелистов Китайской Народной Республики

Цель работы - анализ культурно-исторических особенностей национального музыкального искусства Китая. В статье проанализированы историко-культурные предпосылки становления и особенностей развития музыкального искусства Китая на современном этапе. Выяснено, что на этот процесс влияют такие факторы, как интеграция Китайской Народной Республики в мировое арт-пространство, взаимный обмен европейскими и восточными традициями музыкально-исполнительской культуры, обогащение теории и практики обучения искусству в Китайской Народной Республике лучшими достижениями и передовым опытом зарубежных специалистов, реформирование наииональной системы массового и специализированного музыкального образования, в частности в области академической подготовки исполнителей-виолончелистов. В контексте сказанного актуальным становится раскрытие особенностей учебной и концертно-исполнительской деятельности профессиональных китайских виолончелистов, а также осознание значения их творческих достижений для развития современного инструментально-оркестрового исполнительства и музыкального образования в Китае. Методология исследования опирается на системно-аналитический, компаративистский и историко-культурный методы. В материалах статьи раскрыто, что начальное музыкально-инструментальное обучение учеников-виолончелистов реализуется 8 Китае в рамках школьной или частной практики. Профильное среднее 
и высшее музыкальное образование будущие специалисты получают в музыкальных колледжах, на музыкальных факультетах классических университетов, в консерваториях, академиях, а также в учебных заведениях других стран. Популяризации виолончельного исполнительства в Китае способствуют развитие инструментально-оркестрового искусства, увеличение количества камерных и оркестровых коллективов, организация и проведение международных исполнительских конкурсов, усовершенствование научно-теоретической базы и методики обучения игре на виолончели и другое. Научная новизна состоит в определении состояния развития музыкального образования Китайской Народной Республики, отдельных характеристик профессиональной подготовки исполнителей-виолончелистов в профильных учебных заведениях Китая. В работе осуществлена интерпретация биографических сведений, творческого пути и особенностей реализации концертно-исполнительской, педагогической, организационной и других видов деятельности известных китайских виолончелистов (Йо-Ио Ма, Ван Цзюнь, Тао Ни, Кан Цяосюань и других). Предпринята попытка осветить индивидуально-неповторимые характеристики их личностного и художественного мировосприятия, специфические черты авторского исполнительского стиля, круг музыкальных интересов и предпочтений. Выводы. Определены роль и личный вклад современных китайских виолончелистов в развитие отечественной и мировой инструментально-исполнительской культуры, а также в усовершенствование академического музыкального образования, раскрыт высокий творческий потенциал нового поколения китайских музыкантов-виолончелистов.

Ключевые слова: китайские виолончелисты, профессиональное музыкальное образование, концертно-исполнительская деятельность, международный конкурс.

Актуальність теми дослідження. Академічне інструментальне й оркестрове виконавство в сучасній Китайській Народній Республіці (далі - КНР) переживає період бурхливого і продуктивного розвитку та стає відомим у всьому світі. Це пов'язано з докорінними змінами і перетвореннями, що відбуваються в системі професійної музичної освіти цієї країни, яка реформується під впливом таких чинників, як: інтеграція Китаю у світовий мистецький простір, взаємообмін європейськими та східними традиціями інструментально-виконавської культури, збагачення теорії і практики підготовки музикантів у КНР найкращими здобутками і досвідом фахівців з інших країн, перебудова національної системи масової та спеціалізованої музичної освіти тощо. Одним з актуальних питань $є$ розкриття особливостей освітньої та концертно-виконавської діяльності музикантів-інструменталістів, зокрема 
віолончелістів КНР, у сучасних умовах розвитку світової музичної культури.

Дослідження тенденцій розвитку сучасного музичного мистецтва і виконавства у КНР на зламі XX-XXI ст. простежується в роботах Г. Дівєєвої, Лі Юе, Ло Чжихуей, На Мула, Хуан Сяньюй та інших. Теоретичні та методичні аспекти проблеми підготовки музикантів-віолончелістів, зокрема в Китаї, розглядаються у працях Д. Гудімова, Т. Есаулової, Му Цюаньчжи, Чжан Цін, Чжу Юаньюань та інших.

Мета дослідження - аналіз культурно-історичних особливостей національного музичного мистецтва Китаю та висвітлення особистісного внеску професійних китайських віолончелістів у розвиток сучасного інструментально-оркестрового виконавства й освіти в Китаї.

Виклад основного матеріалу. Із часів Конфуція музика була важливою складовою частиною філософіі, культури, духовного світу китайців, а також потужним чинником формування їхніх естетичних поглядів і почуттів. Давні мислителі надавали музиці пріоритетного значення в галузі освіти й виховання, сфері самопізнання людини, розвитку іiі світоглядних та ціннісних орієнтирів. Вони вважали, що взаємозумовленість і гармонійне співвіднесення складових частин змісту та форми музичних явищ здатні вплинути не тільки на індивідуальне світосприйняття, привнести в життя особистості відчуття краси, рівноваги та логічної упорядкованості, а й допомогти доцільно й ефективно організувати людську спільноту.

Перші професійні музиканти в Китаї з'явилися в давні часи. Їхнє мистецтво супроводжувало церемоніальні події та розваги імператорських кланів, обрядові і культові традиції, трудове життя простого народу. Музичне мистецтво Китаю пройшло довгий і непростий шлях становлення й розвитку, що супроводжувався періодами занепаду й піднесення. Сьогодні національна доктрина розвитку КНР націлена на здобуття країною світового лідерства не тільки в економіці, сфері високих технологій, політиці, а й у галузі музичного мистецтва, зокрема й підготовки професійних виконавців академічної і народної музики.

На противагу традиційній китайській музиці, яка зародилась та розвивалася в досить специфічних умовах китайського суспільства минулих століть, на академічне (професійне) музичне мистецтво потужний та ефективний вплив здійснили 
культура і традиції музичного виконавства інших країн, передусім Європи, Росії, США, Японії. Сьогодні в основі розвитку професійного музичного мистецтва і виконавства у КНР лежить система загальної музичної освіти (шкільної та сімейної).

Відліком початку справжнього ренесансу масового музичного навчання й виховання у КНР прийнято вважати 1949 р., коли керівництвом країни було ухвалено постанови і закони щодо: відкриття музичних шкіл; уведення обов'язкових уроків музики (співів) чотири рази на тиждень у загальноосвітніх навчальних закладах; посилення уваги до вивчення як традиційних національних пісень, так і світової музики; популяризації кращих зразків західної композиції; стимулювання навчання гри на китайських народних і європейських музичних інструментах (фортепіано, скрипка, віолончель, духова група тощо).

Як показує аналіз ситуації, у сучасному Китаї державні музичні школи все ще існують в обмеженій кількості та лише у великих містах (Пекін, Шанхай, Ухань, Сіань, Нанкін, Шеньян, Тяньцзін, Гуанчжоу, Ченду й інші). Музичних коледжів і середніх профільних навчальних закладів теж не вистачає. Це зумовлює той факт, що більшість із тих, хто бажає опанувати мистецтво гри на музичному інструменті або вокалу, вимушені навчатись приватним чином [7].

Як зазначено в роботах Г. Дівєєвої, Лі Юе, для підготовки фахівців-музикантів у 1922 р. при Пекінському університеті було відкрито консерваторію, у 1927 р. - державний музичний коледж (сучасна назва - Шанхайська консерваторія). У своїй діяльності ці навчальні заклади об'єднали досягнення європейської та китайської систем музичної освіти, що були спрямовані на підготовку висококваліфікованих спеціалістів. У Шанхайській консерваторії тоді працювали багато запрошених викладачів-іноземців, які очолювали різні факультети та передавали свої знання і власний досвід китайським студентам. Так, Б. Захаров, С. Аксаков, С. Лєвітін, 3. Прібиткова викладали фортепіано; I. Шевцов та Г. Фельдман навчали гри на віолончелі; А. Фоа, В. Шушлін і О. Черепнін викладали скрипку, вокал і основи композиції. Значний внесок у розвиток музичної теорії і практики зробили китайські викладачі-музиканти: Чжоу Шуан (вокал, сольфеджіо), Сяо Юмей (гармонія, основи композиції, історія музики, оркестровка). 
Такі педагоги, як Чжо Юаньжень, Лю Тяньхуа, Шень Сіньгун, Лі Шутун та інші, на той момент отримали професійну освіту у кращих консерваторіях Європи, США. Протягом XX ст. у Китаї також було відкрито Шеньяньську, Сигуаньську, Уханьську, Тяньцзіньську й інші консерваторії, музичні відділення класичних університетів. При цих навчальних закладах було розпочато роботу курсів підвищення кваліфікації, відкрито відділення аспірантури, підготовлено випуск наукових газет і журналів, а також організовано різноманітні студентські оркестри й інші творчі колективи [2; 4].

Нині професійна музична та музично-педагогічна освіта у КНР функціонує переважно за європейськими зразками та реалізується в таких основних напрямах, як: 1) підготовка вчителів музичного мистецтва для забезпечення масового музичного й естетичного виховання молодого покоління (музичні коледжі, музично-педагогічні відділення університетів); 2) академічна освіта музикантів-виконавців різних профілів (музичні коледжі, консерваторії, академії).

Останнім часом у Китаї спостерігається пожвавлення інтересу до мистецтва виконання на струнно-смичкових інструментах, зокрема на віолончелі. Про популярність віолончельного виконавства свідчить те, що китайці надзвичайно люблять задушевне звучання цього інструмента, яке передає різні відтінки людського голосу й емоційних переживань. Вони із задоволенням відвідують концерти віолончельної музики, а багато хто з них мріє навчитися грати на цьому інструменті.

Проте в Китаї існує певний дефіцит вітчизняних викладацьких кадрів, спостерігається невідповідність між загальноприйнятими положеннями теорії навчання гри на віолончелі й окремими авторськими методиками, відчувається гостра нестача грунтовних наукових досліджень, а також нотно-методичної літератури, підручників, посібників у цій галузі. У контексті цього, як зазначає Д. Гудімов, «така постановка справи зумовила уніфікацію техніки виконання на всіх струнних смичкових інструментах і не могла не відбитися на сторінках віолончельних посібників. Аж до 1806 р. так звані «Методи» були написані не віолончелістами і фактично були комплексними «школами» зі спільними принципами аплікатури і звуковидобування на споріднених інструментах» [1, с. 239]. 
Сьогодні у КНР зростає нове покоління віолончелістів-виконавців, які ставлять собі за мету підкорити світовий музичний Олімп і реалізують це завдяки не тільки своїй бездоганній віртуозній техніці, а й демонстрації високої культури виконавства, самобутності власних інтерпретацій. В арсеналі сучасних китайських віолончелістів є багатий та різноманітний репертуар, основу якого становлять твори М. Афанасьєва, Й. Баха, А. Вівальді, А. Вьєтана, Р. Вагнера, К. Давидова, Ж.Л. Дюпора, Р. Крейцера, Б. Ромберга, А. Рубінштейна, Н. Паганіні, С. Прокоф’єва, Ф. Серве, Р. Шумана, Л. Шпора, I. Штрауса, П. Чайковського, А. Хачатуряна й інших.

Одним із найбільш визнаних у світі віолончелістів $\epsilon$ американський виконавець китайського походження Йо-Йо Ма (1955 р. н.), який також майстерно грає на фортепіано, скрипці та реалізує себе у викладацькій і композиторській діяльності. Йо-Йо Ма познайомився з віолончеллю в чотирирічному віці, одразу проявив свою надзвичайну музичну обдарованість, працелюбність та наполегливість. Навчаючись у Джульярдській школі, Колумбійському та Гарвардському університетах, Йо-Йо Ма виступав 3 оркестром Л. Бернстайна, Гарвардським оркестром Редкліфа, у складі камерних ансамблів та колективів. Сьогодні Йо-Йо Ма є визнаним у світі майстром інтерпретації класичної музики. Віолончеліст також створив власний оркестр під назвою «Великий шовковий шлях», ідеєю діяльності якого є об'єднання музикантів із різних країн. Йо-Йо Ма веде активну концертну та педагогічну діяльність, бере участь як член журі в багатьох музичних конкурсах, співпрацює із провідними фірмами звукозапису - Sony Classical, Blue Note Records та іншими, підтримує молодих музикантів (керує Спілкою дитячих оркестрів у Нью-Йорку).

Музикант завжди перебуває у творчому пошуку, цікавиться новими творами, ідеями, проєктами, зокрема й китайських композиторів. Так, нещодавно Йо-Йо Ма взяв активну участь у реалізації новаторського проєкту Тан Дуна - концерті «Карта» для віолончелі, відео й оркестру (у формі сюїти з 10 п'єс), прем'єра якого відбулась у Бостоні. Це дійство побудоване на синтезі мистецтв. Музичний матеріал супроводжується відеорядом на кіноекрані, що відображає сцени із життя сільських музикантів, які грають на народних інструментах. Для створення цілісного враження на слухачів, активізації 
їхнього сприйняття, досягнення емоційного впливу на свідомість автор концерту використовує цікаві художні прийоми. Так, зображення на відео ритму ударів по воді білизною, яку перуть китайські жінки, синхронно супроводжується аналогічним музичним ритмом різних груп ударних інструментів. Композитор використовує цитати з автентичних народних та популярних китайських пісень, а також за допомогою оркестровки намагається досягти імітації звучання старовинних народних інструментів виконавськими засобами сучасного інструментарію [7].

Музикантом світового рівня XX-XXI ст. є китайсько-американський віолончеліст Ван Цзюнь - один із найкращих виконавців творів епохи бароко (Й. Бах, А. Вівальді й інші). Його творчий потенціал відкрив видатний скрипаль Ісаак Стерн, який відвідав Китай із метою відбору на навчання у США найбільш перспективних учнів. У 16 років Ван Цзюнь вступив до Йельського університету (на музичний факультет), a згодом розпочалася його концертно-виконавська діяльність. Протягом життя Ван Цзюань співпрацював із видатними музикантами, диригентами (К. Аббаді, В. Заввалиш та іншими), оркестрами (Берлінський філармонічний оркестр, Філадельфійський, Чиказький та Лондонський симфонічні оркестри) [5]. Критики і слухачі завжди відзначають яскравий музичний талант і художньо-виконавську майстерність китайського віолончеліста, особливу неповторність його творчого «почерку». Музиканта часто залучають до роботи у складі авторитетних журі, зокрема на Міжнародному юнацькому конкурсі імені П. Чайковського, а також запрошують виступати з майстер-класами.

Відомим нині в багатьох країнах світу виконавцем академічної музики є китайський віолончеліст Тао Нi (1984 р. н.), який здобув професійну освіту в Шанхайській консерваторії, а згодом продовжив навчання в Канаді та США (Бостонська консерваторія та Школа Колбурна в Лос-Анджелесі). $\mathrm{E}$ лауреатом численних міжнародних виконавських конкурсів (III премія 15 Міжнародного юнацького конкурсу ім. П. Чайковського в Седаї, 1995 р.; II премія 18 Міжнародного конкурсу виконавців на струнних інструментах ім. I. Кляйна в Сан-Франциско, 2003 р.; I премія 23 Міжнародного конкурсу інструменталістів у Пасадені, 2008 р.). На своїх виступах молодий, але серйозний і вдумливий музи- 
кант завжди демонструє блискучу художню техніку, глибину проникнення в авторський задум, вишуканість і чистоту виконавської інтонації. Талант і майстерність Тао Ні реалізуються у співпраці з такими виконавцями, як I. Перельман, А. Кавафян, А. Кашкашьян та інші, у складі камерних і симфонічних оркестрів Бостона, Калгарі, Шанхая, Цинцинаті, Лос-Анджелеса. У репертуарі віолончеліста чільне місце належить творам Й. Баха, К. Піатті, Р. Шумана, П. Чайковського, П. Гіндеміта [6].

Плеяду молодих китайських віолончелістів, які нині досягають міжнародного визнання, представляють такі імена: Кан Цяосюань, Ла Лі, Чен Ібай, Наміса Сунь, Чжу Бейлянь, Бонь Ян Тіан, Кін Лі Вей, Чжен Сі й інші. Ці віолончелісти - представники нової формації музикантів, які, з одного боку, продовжують класичні традиції інструментального виконавства, 3 іншого - шукають і викристалізовують свій власний стиль, не бояться експериментувати, ставити перед собою амбіційні цілі. Це покоління виконавців-конкурсантів, які виборюють високі місця на п’єдесталах переможців завдяки самовідданій і важкій щоденній праці, власній обдарованості та бажанню поділитися своїм мистецтвом з іншими людьми.

Так, нещодавно заявив про себе молодий виконавець-віолончеліст Чен Ібай, який протягом навчання в середній музичній школі при Шанхайській консерваторії неодноразово брав участь у роботі віолончельної академії Рутесхайма та майстер-класах таких видатних майстрів, як Д. Герингас, Й.П. Майнц, Ван Цзян, М. Рузі, Г. Швабу, Лівей Цинь, Цуєсі Цуцумі й інші. Зараз молодий віолончеліст продовжує навчання в Берлінському університеті мистецтв та успішно реалізує себе в концертній та конкурсній діяльності (фестиваль "Morningside Music Bridge", 2013 p., III премія 11 Міжнародного конкурсу віолончелістів імені Вітольда Лютославського в Польщі).

На світовому музичному небосхилі нещодавно з'явилось ім'я молодого, але неординарного і надзвичайно талановитого китайського музиканта Кан Цяосюань. Як зазначає Т. Есаулова, виконавець поєднує інтерпретацію академічних творів для віолончелі та традиційної китайської музики в сучасних обробках і аранжуваннях, зокрема в дуеті зі скрипкою ерху. Віолончеліст приділяе значну увагу популяризації композицій сучасних китайських авторів («Сон метелика» Чжао Цзи- 
пін, «Весняна святкова увертюра» Лі Хуанчжи, «Моя Батьківщина» Лю Веньцзинь тощо). Кан Цяосюань є солістом Сучжоуського китайського оркестру, часто гастролює по країні, а також у Росії, Японії, Германії, Румунії [3].

Перспективними представниками вітчизняної віолончельної школи виступають юні музиканти Чжен Сi, Ла Лі, Наміса Сунь. Молоді виконавці беруть активну участь у міжнародному конкурсному житті, виступають у номінаціях молодших учасників. Так, Наміса Сунь здобула перемогу (I премія) на конкурсі імені Святослава Кнушевицького (м. Саратов, Росія). Перемогу у групі вона розділила з талановитим віолончелістом Арсенієм Ставицьким (м. Київ, Україна). Чжен Сі став володарем III премії цього ж конкурсу. Юні музиканти блискуче виконали свої програми: Концерт для віолончелі 3 оркестром Й. Гайдна, Варіації на тему рококо П. Чайковського, I частини концертів А. Дворжака і Д. Кабалевського, рапсодію А. Хачатуряна у перекладі для віолончелі і фортепіано. Переможницею (лауреат I преміi) 8 Міжнародного юнацького конкурсу імені П. Чайковського в номінації «Учасники до 17 років» стала дівчинка-віолончелістка Ла Лі. Технічно бездоганне й натхненне фінальне виконання концерту К. Сен-Санса дозволило їй перемогти 46 учасників групи і підкорити своїм мистецтвом усіх членів журі, головою якого був Е. Тестелец (Латвія).

Висновки. Отже, визнані майстри і молоді китайські музиканти-віолончелісти демонструють нині високий рівень художньої і виконавської майстерності, а також надзвичайну працелюбність й волю до перемоги. Досягнення найвищих результатів $є$ дуже важливим для цього нового й сміливого покоління, адже китайці - це сильний духом народ, націлений на самореалізацію та боротьбу за перспективне майбутнє. Їхня творчість продовжує і розвиває найкращі традиції вітчизняного і світового виконавства на струнно-смичкових інструментах, популяризує мистецтво гри на віолончелі.

\section{СПИСОК ЛІТЕРАТУРИ}

1. Гудимов Д. Школы игры на виолончели XVIII-XXI веков : исторический обзор, традиции и современные новации. Вестник Московского государственного университета культуры и искусств. 2014. № 3 (59). С. $237-243$.

2. Дивеева Г. Шанхайская национальная консерватория в 1920-1940-е гг.: к проблеме взаимодействия с традициями российс- 
кого музыкального образования. Общество. Среда. Развитие (Terra Humana). Санкт-Петербург, 2014. № 1 (30). С. 137-141.

3. Эсаулова Т. На конкурсе имени Святослава Кнушевицкого победил российский виолончелист. URL: http://rg.ru>reg-pfo>na-kon (дата обращения: 15.02.2020).

4. Ли Юе. Китайское музыкальное образование в XX веке и его состояние на рубеже XX-XXI веков. Вестник Кемеровского государственного университета культуры и искусств. 2017. № 40. С. 225-231.

5. Ло Чжихуэй. Концертная жизнь современного Китая : дис. ... канд. искусствовед.: 17.00.02. Санкт-Петербург, 2016. 213 с.

6. Тао Ни. URL: https://tch15/medici.tv>artist>tao-ni (дата обращения: 14.05.2020).

7. Чжу Юаньюань. Претворение национальных истоков в концерте «Карта» для виолончели, видео и оркестра Тан Дуна. Проблеми взаємодії мистецтв, педагогіки та теорії і практики освіти. Харків, 2015. Вип. 42. С. 237-243.

\section{REFERENCES}

1. Gudimov, D.B. (2014). Shkoly igry na violoncheli XVIIIXXI vekov: istoricheskii obzor, traditsii i sovremennyie novatsii. Vesnik MGUKI, 3 (59), 237-243. [in Russian]

2. Diveieva, G.A. (2014). Shankhaiskaia natsionalnaia konservatoriia v 1920-1940-ie gg.: k probleme vzaimodeistviia s traditsiiami rossiiskogo muzykalnogo obrazovaniia. Obshchestvo. Sreda. Razvitiie (Terra Humana), 1 (30), 137-141. [in Russian]

3. Esaulova, T. Na konkurse imeni Sviatoslava Knushevitskogo pobedil rossiiskii violonchelist. Retrieved from: http://rg.ru>reg-pfo>nakon

4. Yue, Lee. (2017). Kitaiskoie muzykalnoie obrazovaniie v XX veke I iego sostoianiie na rubezhe XX-XXI vekov. Vestnik Kemerovskogo gos. un-ta kultury $i$ iskusstv, 40, 225-231. [in Russian]

5. Chzhikhuei, Lo. (2016). Kontsertnaia zhyzn sovremennogo Kitaia. Candidate's thesis. Sankt-Peterburgskaia gos. konservatoriia (akademiia) imeni N.A. Rimskogo-Korsakova.

6. Ni, Tao. Retrieved from: https://tch15/medici.tv>artist $>$ tao-ni

7. Yuanyuan, Chzhu. (2015). Pretvoreniie natsionalnykh istokov v kontserte "Karta" dlia violoncheli, video i orchestra Tan Duna. Problemy vzaiemodiyi mystetstv, pedahohiky ta teoriyi $i$ praktyky osvity: $z b$. nauk. statei, 42, 237-243. Kharkiv. [in Ukrainian] 